\title{
The effects of turmeric (curcumin) on tumor suppressor protein (p53) and estrogen receptor $(E R \alpha)$ in breast cancer cells
}

This article was published in the following Dove Press journal:

Breast Cancer - Targets and Therapy

10 March 2017

Number of times this article has been viewed

\section{Kelly Hallman \\ Katie Aleck \\ Brigitte Dwyer \\ Victoria Lloyd \\ Meghan Quigley \\ Nada Sitto \\ Amy E Siebert \\ Sumi Dinda}

School of Health Sciences, Prevention Research Center, Oakland University, Rochester, MI, USA
Correspondence: Sumi Dinda Biomedical Diagnostic and Therapeutic Sciences, $3164 \mathrm{HHB}$, School of Health Sciences, 433 Meadow Brook Road, Oakland University, Rochester, MI 48309, USA

Tel +l 2483648676

Fax +I 2483648657

Email sdinda@oakland.edu

\begin{abstract}
Curcumin (CUR) is a compound that has antibacterial, antiviral, anti-inflammatory, and anticancer properties. In this study, we have analyzed the effects of CUR on the expression of $E R \alpha$ and $\mathrm{p} 53$ in the presence of hormones and anti-hormones in breast cancer cells. Cells were cultured in a medium containing charcoal-stripped fetal bovine serum to deplete any endogenous steroids and treated with CUR at varying concentrations or in combination with hormones and anti-hormones. Protein analysis revealed a relative decrease in the levels of p53 and ER $\alpha$ upon treatment with 5-60 $\mu \mathrm{M}$ CUR. In cell proliferation studies, CUR alone caused a 10-fold decrease compared with the treatment with estrogen, which suggests its antiproliferative effects. Delineating the role of CUR in the regulation of $\mathrm{p} 53, \mathrm{ER} \alpha$, and their mechanisms of action may be important in understanding the influence of CUR on tumor suppressors and hormone receptors in breast cancer.
\end{abstract}

Keywords: breast cancer, tumor suppressors, p53, estrogen, anti-estrogens, female sex steroids, turmeric

\section{Introduction}

In the USA alone, breast cancer is the second leading cause of cancer death in women. ${ }^{1}$ Invasive breast cancer (IBC) is known to develop after the progression of multiple stages, one of the later stages being referred to as ductal carcinoma in situ (DCIS). DCIS is an intraductal neoplastic proliferation of epithelial cells that do not invade through the basement membrane layer to the breast stroma. ${ }^{1-3}$ In several cases, it is known to be preliminary to IBC, and it has been suggested that the proliferation of DCIS is dependent on the presence of estrogen. Once the DCIS becomes cancerous, it is known as ductal carcinoma, which is a form of hormone-dependent breast cancer. ${ }^{1-3}$ The T-47D cell line used in our experiments was isolated from infiltrating ductal carcinoma of the breast and is positive for both estrogen receptor (ER) and progesterone receptor (PR).

Curcumin (CUR), also known as diferuloylmethane, has the chemical formula 1,7-bis(4-hydroxy-3-methoxyphenyl)-1,6-heptadiene-3,5-dione. It is an active polyphenolic compound that is isolated from the spice turmeric (Curcuma longa). Its chemical structure includes $\alpha, \beta$ unsaturated $\beta$-diketones, along with hydrophobic phenyl groups that are vital to its binding activity with molecular targets. While CUR is commonly used as a spice, food additive, and dietary pigment, it has captivated attention for having antibacterial, antiviral, anti-inflammatory, and anticancer properties. ${ }^{4-6}$ It is also considered to have valuable potential with regards to the targeting of various cancers. ${ }^{6}$ 
CUR also exhibits anticancer effects in cancer stem-like cells (CSCs). It has been shown to considerably diminish microtentacles of the plasma membrane of CSCs, thereby preventing reattachment of the cells at distant tissues. ${ }^{7}$ It has also been demonstrated that CUR restores expression of the tumor suppressor gene E-cadherin in breast CSCs. ${ }^{8}$

A significant number of other reports have indicated that the anticancer effects of CUR are due to the regulation of multiple molecular targets involved in tumorigenesis, angiogenesis, metastasis, invasion, proliferation, and apoptosis. It is also known to significantly reduce the harmful reactions of reactive oxygen species. ${ }^{9-23}$ These anticancer effects are also demonstrated when CUR is present in different analogs, or when combined with other compounds. ${ }^{24-32}$ CUR-loaded nanoparticles may also have potential applications in breast cancer therapy and other various cancers. ${ }^{33,34}$

Numerous studies have demonstrated that CUR exhibits multiple effects in the suppression of human breast cancer cells in vitro, leading to the incorporation of CUR in ongoing clinical trials. ${ }^{35-39}$ It has been reported that CUR hinders the growth of T-47D breast cancer cells in a concentrationdependent manner. ${ }^{40}$

CUR-induced apoptosis has been associated with stimulation of the p53 pathway. ${ }^{41}$ Consistent with our findings that CUR decreases the regulation of p53 in T-47D breast cancer cells, it has been demonstrated that CUR impairs the expression and function of p53 in colon cancer cells through inhibition of its gene transcription. ${ }^{42}$ Literature has shown that the p53 gene is mutated in the T-47D breast cancer cell line. However, the actual quantity of mutated versus wild-type p53 remains unknown in the T-47D cells. ${ }^{43-45}$ Studies have also shown that in estrogen receptor (ER)-positive breast cancer cells, the antiproliferative effects of CUR are dependent on the presence of estrogen. ${ }^{11,46}$ Reports indicate that breast cancer cells treated with CUR show a significant downregulation in the expression of ER $\alpha$ compared with the control cells. ${ }^{40}$ Previous studies, including studies from our laboratory, have shown that treatment with estrogen in T-47D breast cancer cells causes increased cell proliferation and upregulation of the tumor suppressor protein, p53. ${ }^{47-49}$ In this study, we have analyzed the effects of CUR on the expression of ER $\alpha$ and p53 in the presence of estrogen, bisphenol-a (BPA), and antiestrogens in T-47D breast cancer cells. Our studies validate CUR's potential as a therapeutic agent for breast cancer.

\section{Methods and materials}

\section{Cell culture and treatment with ligands}

T-47D human breast cancer cells (ATCC ${ }^{\circledR}$ HTB-133 ${ }^{\text {TM}}$; American Type Culture Collection, Rockville , MD, USA) were routinely cultured in RPMI-1640 media (Hyclone, Logan, UT, USA) containing $2 \mathrm{mM}$ l-glutamine, $25 \mathrm{mM}$ HEPES, $24 \mathrm{mM}$ sodium bicarbonate, $0.5 \% 100 \times$ non-essential amino acids, $100 \mathrm{U} / \mathrm{mL}$ penicillin, $0.1 \mathrm{mg} / \mathrm{mL}$ streptomycin, $0.25 \mathrm{mg} / \mathrm{mL}$ amphotericin B (Hyclone), and $0.14 \mathrm{IU} /$ $\mathrm{mL}$ insulin (Sigma, St Louis, MO, USA) supplemented with $10 \%(\mathrm{v} / \mathrm{v})$ fetal bovine serum (FBS; Hyclone). In all studies, cells were plated in $10 \% \mathrm{FBS}$ media and incubated at $37^{\circ} \mathrm{C}$ in the presence of $5 \% \mathrm{CO}_{2}$. After the cells were allowed to attach and grow for 48 hours, they were cultured in 5\% FBS stripped with dextran-coated charcoal (DCC-FBS), which ensures steroid-free treatment conditions, for a total of 6 days with fresh medium added every 48 hours. On the sixth day, semi-confluent cells were treated with various ligands for 3 or 24 hours. Stock solutions of the ligand used for cell treatment were prepared in DMSO to a 1000-fold higher concentration than the final concentration to be extracted.

\section{Extraction of cells}

Following the removal of media by aspiration, cells were washed with ice-cold Hanks balanced salt solution and scraped into $200 \mu \mathrm{L}$ of RIPA lysis buffer. The cells were thawed on ice. To prepare a high-speed supernatant (HSS), the cells were centrifuged for 15 minutes at $15,000 \times g$ at $4^{\circ} \mathrm{C}$. The HSS for each sample was stored at $-80^{\circ} \mathrm{C}$ until further use.

\section{SDS-PAGE and Western blot analysis}

Extracted protein supernatants were quantified using the Bradford method to standardize the amount of protein to be loaded into each lane. After the supernatants for each sample were denatured for 3 minutes at $85^{\circ} \mathrm{C}, 30 \mu \mathrm{g}$ aliquots of total protein were loaded into each lane on a $7.5 \%$ polyacrylamide gel. The gels were subjected to electrophoresis to perform protein band separation. Proteins were wet transferred onto an Immobilon-P polyvinylidene fluoride (PVDF) membrane (Millipore, Bedford, MA,USA) in a tris-glycine buffer system (0.025\% SDS and $15 \%$ methanol) contained in a Bio-Rad (Hercules, CA, USA) trans blot cell set to $110 \mathrm{~V}$ for 45 minutes. Membranes were blocked for 1 hour in $5 \%(\mathrm{w} / \mathrm{v})$ non-fat dry milk (NFDM) in TBS-T (20 mM Tris-HCl, 140 $\mathrm{mM} \mathrm{NaCl}, \mathrm{pH} 7.4,0.1 \%[\mathrm{v} / \mathrm{v}]$ Tween 20$)$ and incubated with primary antibody anti-ER $\alpha$ clone F-10 and anti-p53 (Santa Cruz) diluted 1:500 in 5\% (w/v) NFDM in TBS-T for 2 hours. Actin bands were probed by anti-actin (monoclonal antibody clone C4) (Millipore). ER $\alpha$ and p53 levels were normalized to protein levels of the evolutionarily conserved actin protein according to the manufacturer's protocol. After washing with TBS-T ( $3 \times 10$ minutes) and incubation with horse radish peroxidase (HRP)-conjugated goat antimouse 
$\mathrm{IgG}_{2 \mathrm{a}}$ secondary antibody (Santa Cruz) diluted 1:1000 in $5 \%(\mathrm{w} / \mathrm{v})$ NFDM in TBS-T for 1 hour, blots were developed using Amersham ECL Prime (GE Healthcare Biosciences, Piscataway, NJ, USA). ER $\alpha$ and $\mathrm{p} 53$-specific bands were visualized using the Bio-Rad Chemi-Doc XRS + System. After immunoblotting, the PVDF membranes were stained with Coomassie blue to ensure the correct normalization against total protein levels and full transfer of protein. The protein band density on each membrane was quantified using the Image Studio Lite program version 3.1 (LI-COR Biosciences, Lincoln, NE, USA).

\section{Cell viability and apoptosis assays}

All growth studies were conducted in 12-well culture plates. To ensure active, non-confluent cell populations during treatment duration, 12-well culture plates were initially seeded with $3.0 \times 10^{4}$ cells per well in $1 \mathrm{~mL}$ culture medium containing $10 \%$ FBS. Studies were limited to 7-day total duration to correlate with the results of Western blot analyses. On the seventh day, the cells were trypsinized and removed from individual wells of the culture plate. Cells were stained with propidium iodide (PI) for viability assays and fluorescein isothiocyanate-conjugated Annexin $\mathrm{V}$ for apoptosis assays per manufacturer's instruction (Cellometer Inc., Lawrence, MA, USA). The cells underwent imaging cytometry by the Cellometer Vision CBA and FCS Express- 6 software. The fluorescent threshold in the software was set to $0 \%$ to measure total fluorescence of each counted cell from the captured images. The measured fluorescence intensities were exported to Microsoft Excel and converted to FCS file for analysis in the De Novo Software. ${ }^{55}$

\section{Immunofluorescence and confocal microscopy}

T-47D cells were plated on cover slips in 12-well plates (30,000 cells/well) and cultured for 48 hours in a $10 \%$ FBS medium. The medium was then changed to $5 \%$ DCC-FBS, and fresh medium was added at 2-day intervals. The cells were cultured in this medium for a total of 4 days. On the fourth day, the ligands were suspended in 5\% DCC-FBS media, and semi-confluent cells were treated for 24 hours.

\section{Cellular localization of $p 53$ by immunocytochemistry}

The cells were fixed on cover slips for 10 minutes with $1 \%$ formalin in phosphate-buffered saline (PBS), permeabilized with ice-cold acetone and methanol (50:50), and washed three times with PBS. Staining procedures were performed in a humidified chamber at $23^{\circ} \mathrm{C}$. Cells were incubated in $10 \%$ goat serum (Sigma) to suppress nonspecific binding of $\mathrm{IgG}$, followed by 3 hours incubation with 1:150 dilution of anti-p53 (F-10) monoclonal antibody. After washing with PBS, cells were incubated for 3 hours with 1:200 dilution of antimouse IgG conjugated with Cy3 (Jackson Immuno Research Laboratories, West Grove, PA, USA). Cover slips were washed in PBS and incubated for 2 minutes in $1 \mu \mathrm{g} / \mathrm{mL}$ DAPI dissolved in PBS. Cells were washed three times in PBS, mounted with Fluoromount-G (Electron Microscopy Sciences, Hatfield, PA, USA) and stored in the dark at $4^{\circ} \mathrm{C}$.

\section{Structural analysis by DIC}

DIC images were acquired by using the DIC objectives with Nikon Digital Eclipse C1 Plus confocal microscope. The distribution of three-dimensional fluorescent structures was analyzed using a Nikon Digital Eclipse C1 Plus confocal microscope. NIS elements software (Nikon Instruments, Melville, NY, USA) was used for noise reduction and threedimensional reconstruction of the images.

\section{Statistical analyses}

The results are expressed as mean \pm SEM. Statistical significance was determined by Kruskal-Wallis test followed by post-hoc analysis using Mann-Whitney $U$ test. The $p$ values were adjusted for multiple testing corrections using the false discovery rate. Differences are considered significant at $p<0.05$. Statistical analyses were carried out using SPSS for Windows version 11.5 (SPSS Inc., Chicago, IL, USA).

\section{Results}

\section{Effects of CUR on cellular viability and the regulation of $E R \alpha$ and $p 53$ levels: concentration dependency}

Figure 1 demonstrates the concentration-dependent effects of CUR on cell viability and the expression of ER $\alpha$ and p53 protein levels. To examine the effects on cell viability, the T-47D cells were treated with 5-100 $\mu \mathrm{M}$ CUR for 6 days. Cellular viability was then determined by propidium iodide (PI) staining and image cytometry. As shown in Figure 1A, 20-100 $\mu$ M CUR significantly decreases T-47D cell viability as compared with the control. CUR at lower concentrations $(5-10 \mu \mathrm{M})$ did not display a significant effect on the cell viability compared with the control.

T-47D cells were treated with 5-80 $\mu \mathrm{M}$ CUR for a duration of 24 hours. The cells were then subjected to 

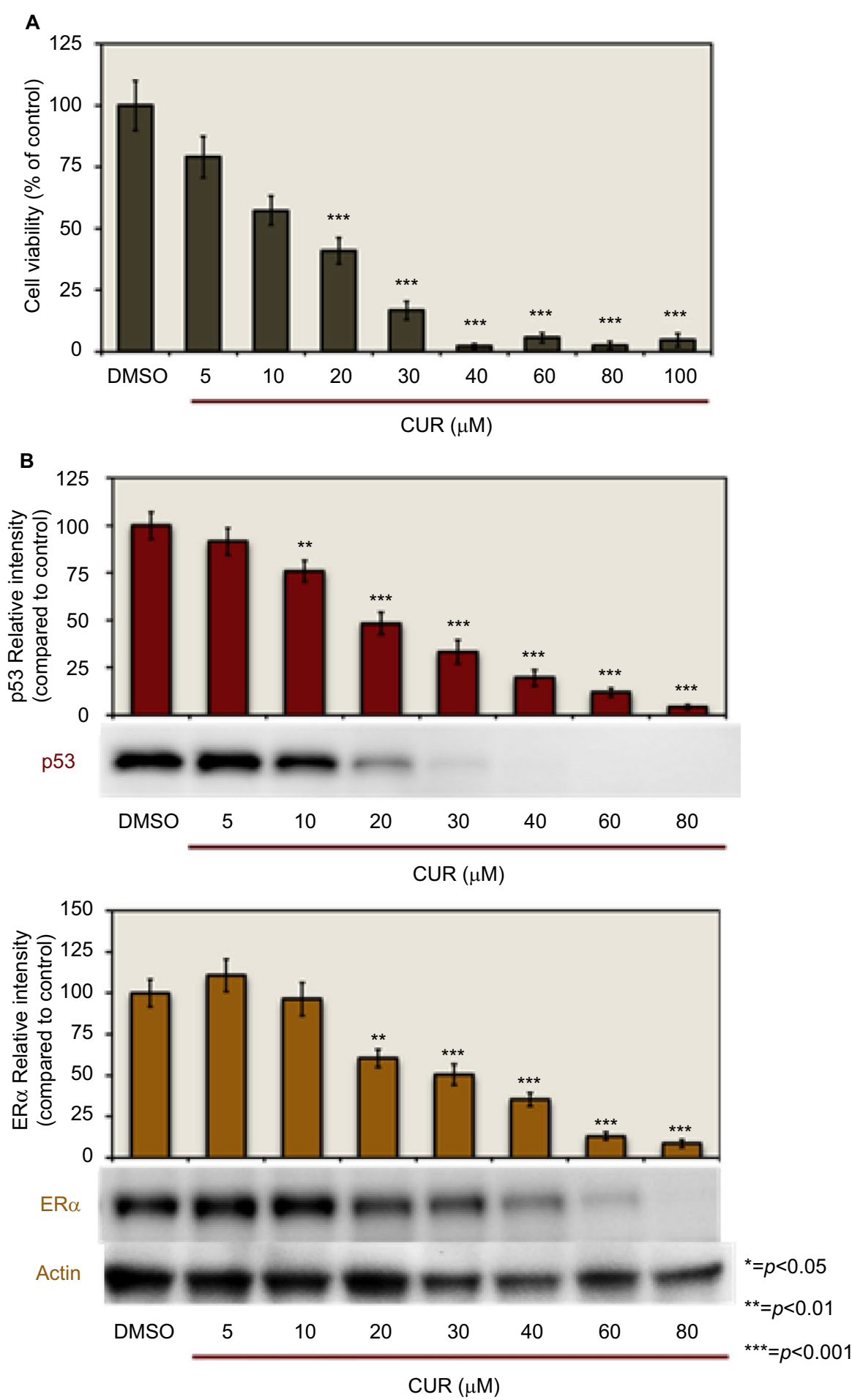

Figure I Concentration-dependent effects of CUR: curcumin decreases T-47D cell viability and downregulates p53 and ER $\alpha$ protein expression. Notes: (A) T-47D cells were treated for 6 days with 5-100 $\mu$ M curcumin, and cell viability was determined by PI staining and image cytometry. (B) T-47D cells were treated for 24 hours with 5-80 $\mu \mathrm{M}$ curcumin and subjected to sodium dodecyl sulfate-polyacrylamide gel electrophoresis and Western blot analysis. The relative intensities of each band were compared with vehicle control (DMSO). Representative blots from three independent experiments are shown.

Abbreviations: CUR, curcumin; DMSO, dimethyl sulfoxide; $\mathrm{ER} \alpha$, estrogen receptor; PI, propidium iodide.

sodium dodecyl sulfate-polyacrylamide gel electrophoresis (SDS-PAGE) and Western blot analysis to examine the concentration-dependent effects of CUR on the level of $E R \alpha$ and p53 (Figure 1B). The relative densities of each of the protein bands were compared with the control. Upon examination of each of the densities, Figure 1B shows that 20-80 $\mu \mathrm{M}$ CUR significantly downregulates both ER $\alpha$ and p53 protein levels. 


\section{Differential interference contrast microscopy of $60 \mu$ M CUR cytotoxicity in T-47D cells}

Differential interference contrast (DIC) images were taken of the T-47D cells to see the contour of the cells (Figure 2A). T-47D cells were treated with $60 \mu \mathrm{M}$ CUR for 6 days, and images were acquired as described in Methods and Materials section. The merged images in Figure 2A indicate that $60 \mu \mathrm{M}$ CUR depleted the T-47D cells.

\section{Effects induced by $60 \mu \mathrm{M}$ CUR in combination with MG- 132}

MG-132 is a proteasomal inhibitor that is known to prevent the degradation of short-lived proteins. Therefore, it is a valuable research tool for examining the cellular degradation through the proteasome pathway. ${ }^{50,51}$ To determine whether CUR is an inhibitor of proteasomal degradation, $60 \mu \mathrm{M}$ CUR was analyzed to verify if MG-132 reversed its effects on the downregulation of protein levels (Figure 2B).

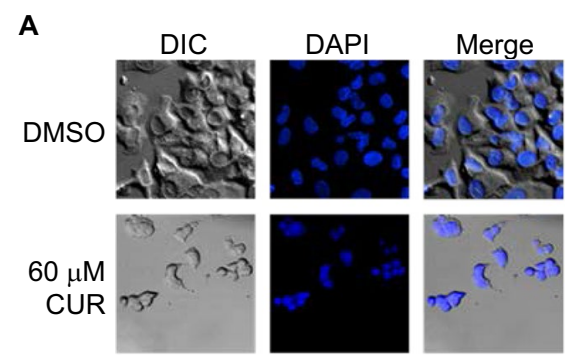

B

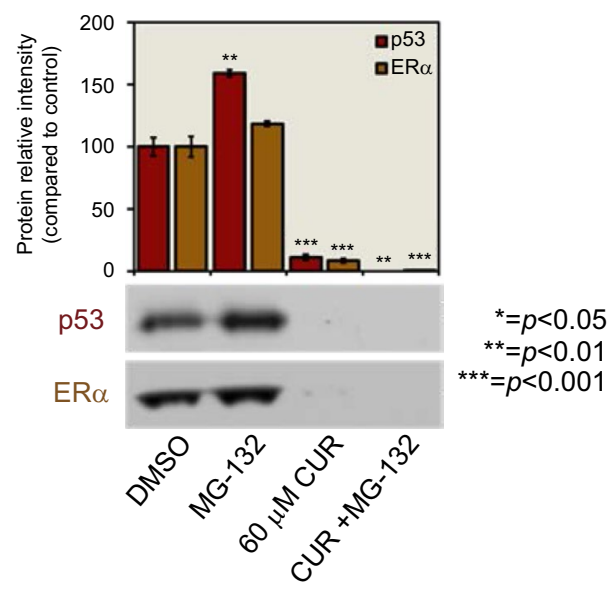

Figure 2 Effects induced by $60 \mu \mathrm{M}$ CUR.

Notes: (A) Differential interference contrast microscopy of $60 \mu \mathrm{M}$ curcumin cytotoxicity in T-47D cells. T-47D cells were treated for 6 days with $60 \mu \mathrm{M}$ curcumin, and images were acquired by Cellometer Vision CBA and FCS Express-6 software. (B) Downregulation of $\mathrm{p} 53$ and $\mathrm{ER} \alpha$ by $60 \mu \mathrm{M}$ curcumin is not reversed by the proteasomal inhibitor MG-132. T-47D cells were pretreated for 30 minutes with $10 \mu \mathrm{M}$ MG-132 followed by 3 hours treatment with $60 \mu \mathrm{M}$ curcumin. Protein extracts were subjected to sodium dodecyl sulfate-polyacrylamide gel electrophoresis and Western blot analysis, and the relative intensities of each band were compared with vehicle control (DMSO). Representative blots from three independent experiments are shown. Abbreviations: CUR, curcumin; ER $\alpha$, estrogen receptor; DIC, Direct Image Contrast; DAPI, diamidino-2-phenylindole; DMSO, dimethyl sulfoxide.
T-47D cells were pretreated with $10 \mu \mathrm{M}$ MG-132 for 30 minutes, followed by a 3-hour treatment with $60 \mu \mathrm{M}$ CUR. Protein extracts were subjected to SDS-PAGE and Western blot analysis, and the relative densities of each band were compared with control (dimethyl sulfoxide [DMSO]), as described in Methods and Materials section. As indicated in Figure 2B, MG-132 did not reverse the effects of $60 \mu \mathrm{M}$ CUR, which suggests that the downregulation of protein levels caused by CUR is not due to mechanistic causes but rather due to its cytotoxicity to the cells.

\section{Effects of 20 and $60 \mu M$ CUR on the apoptosis of T-47D cells}

As illustrated in Figure 3, scatter plots following Cellometer Vision CBA and FCS Express-6 Analysis show an increased trend in the apoptotic/necrotic cell population following incubation with $60 \mu \mathrm{M}$ of CUR treatment for 6 hours compared with the negative controls. This trend explains a shift from the apoptotic (annexin V-positive only) to necrotic (annexin V and PI positive) cell population. This trend seems to increase when the cells were treated with $60 \mu \mathrm{M}$ of CUR for 24 hours. However, treating the cells with $20 \mu \mathrm{M}$ of CUR has shown a lesser trend of apoptotic/necrotic cell population in 6 and 24 hours. $^{52-55}$

\section{Effects of CUR on the immunolocalization of $\mathrm{p} 53$ in T-47D cells}

Along with Western blot studies (Figures 1B and 5B), image analysis was performed by confocal microscopy involving immunofluorescence to determine the cytolocalization of cel-

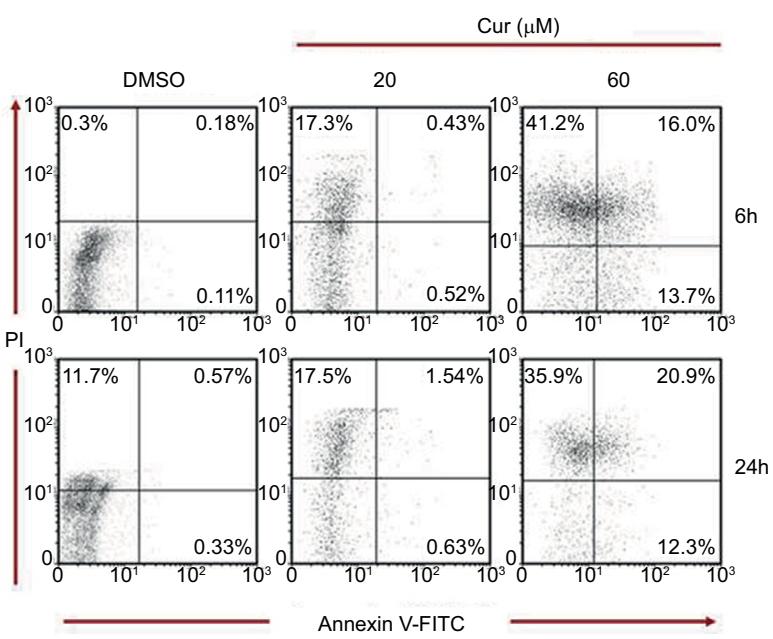

Figure 3 Apoptosis assay: effects of 20 and $60 \mu \mathrm{M}$ curcumin on T-47D cells. Notes: T-47D cells were treated with 20 and $60 \mu M$ curcumin for 6 or 24 hours and analyzed for Annexin V-PI positivity by image cytometry which were acquired by Cellometer Vision CBA and FCS Express- 6 software.

Abbreviations: CUR, curcumin; DMSO, dimethyl sulfoxide; PI, propidium iodide. 
lular p53. 4',6-Diamidino-2-phenylindole (DAPI) is used to stain the nuclei of the cells so that the nuclei will be displayed in the image analysis (Figure 4). As shown in Figure 4, p53 is localized exclusively in the nuclei of the T-47D cells. The control group (DMSO) represents cells grown in a charcoaltreated serum that displays immunofluorescence localized in the nuclei of the T-47D cells. Treatments of $20 \mu \mathrm{M}$ and $60 \mu \mathrm{M}$ CUR did not affect the cytolocalization of cellular p53, as the image analysis shows p53 to still be localized in the nucleus (Figure 4). The images of the cells stained for the nuclei and stained for p53 were merged to further demonstrate that p53 is localized exclusively in the nuclei.

\section{Effects of CUR in combination with ER agonists and antagonists on cellular viability and expression of $E R \alpha$ and $p 53$}

Figure 5 displays the effects of ER agonists and antagonists in combination with CUR. T-47D cells were treated with 20 and $60 \mu \mathrm{M}$ CUR, $10 \mathrm{nM} \mathrm{E}, 600 \mathrm{nM}$ BPA, $1 \mu \mathrm{M}$ ICI, and $1 \mu \mathrm{M}$ tamoxifen (TAM) either alone or in combination. As mentioned in Methods and Materials section, the cells studied for cell viability were treated for 6 hours, and the cells being studied for $\mathrm{p} 53$ and ER $\alpha$ expression by Western blot analysis were treated for 24 hours. The data show that even with the addition of the anti-estrogens ICI and TAM, the estrogen $\mathrm{E}_{2}$, and the ER agonist BPA, the effect of CUR on T-47D cell viability could not be reversed (Figure 5A).

Figure $5 \mathrm{~B}$ indicates that when the cells were treated with 20 and $60 \mu \mathrm{M}$ CUR, the level of p53 protein expression was significantly downregulated compared with the control. The

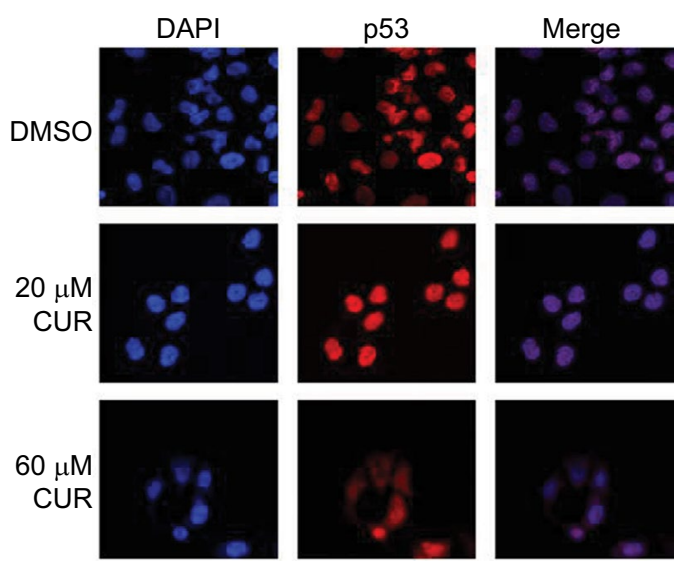

Figure 4 Effects of CUR on the immunolocalization of p53 in T-47D cells. Notes: Image analysis was performed by confocal microscopy involving immunofluorescence to determine the cytolocalization of cellular p53. Treatments of 20 and $60 \mu \mathrm{M}$ CUR did not affect the cytolocalization of cellular p53. The images of the cells stained for the nuclei and stained for $p 53$ were merged to further demonstrate that $\mathrm{p} 53$ is localized exclusively in the nuclei.

Abbreviations: CUR, curcumin; DAPI, diamidino-2-phenylindole; DMSO, dimethyl sulfoxide. addition of $\mathrm{E}_{2}, \mathrm{ICI}$, and TAM to the treatment of $20 \mu \mathrm{M}$ CUR did not alter the significant downregulation of $\mathrm{p} 53$, but the addition of BPA with $20 \mu \mathrm{M}$ CUR had no effect. The additions of $\mathrm{E}_{2}, \mathrm{BPA}, \mathrm{ICI}$, and TAM to the $60 \mu \mathrm{M}$ treatment of CUR still resulted in the downregulation of $\mathrm{p} 53$.

As shown in Figure 5B, the expression of ER $\alpha$ is also significantly downregulated compared with the control by 20 and $60 \mu \mathrm{M}$ CUR. It is also demonstrated that the addition of $\mathrm{E}_{2}$, BPA, ICI, and TAM to both 20 and $60 \mu \mathrm{M}$ CUR did not reverse the downregulation of ER $\alpha$ expression (Figure 5B).

\section{Discussion}

Our studies demonstrate that 20-80 $\mu \mathrm{M}$ CUR significantly downregulates both p53 and ER $\alpha$ protein levels with a concomitant decrease in T-47D cell viability. Other studies involving different breast cancer cell lines treated with CUR, such as BT-483 and MDA-MB-23, have shown a significant decrease in cell proliferation. For example, 48-hour treatments of $5 \mu \mathrm{L} / \mathrm{mL}$ CUR inhibited proliferation of BT-483 cells by $60 \%-70 \%$ and MDA-MB-23 cells by $50 \%-60 \%{ }^{56}$ CUR has been found to be highly cytotoxic to some breast cancer cell lines. This is consistent with our findings that the proteasomal inhibitor MG-132 did not reverse the effects of $60 \mu \mathrm{M}$ CUR on the downregulation of $\mathrm{ER} \alpha$ and $\mathrm{p} 53$ in T-47D cells. ${ }^{57}$ In our studies, the presence of anti-estrogens and ER agonists, including BPA, did not reverse the effects of CUR on T-47D cell viability, and this reduction could not be explained by an induction of apoptosis under our experimental conditions. In addition, when CUR is used in combination with ER $\alpha$ agonists and antagonists, the alterations in $\mathrm{p} 53$ protein expression do not correlate with alterations in cell viability.

It has been shown that CUR inhibits the phosphorylation of p53, its ability to bind to DNA, and the transactivation of genes that correlate with its function as a tumor suppressor. ${ }^{42}$ However, our experiments suggest that the CUR-induced effects on the T-47D cells are not due to a mechanism involving p53 and appear to involve a mechanism that includes proteins other than p53 and ER $\alpha$. CUR has also been found to inhibit the expression of the leptin gene in T-47D breast cancer cells, and this inhibition was positively associated with a decrease in the expression of ER $\alpha .^{40}$ Experiments involving the multiple effects of CUR on human breast cancer cells have shown that the antiproliferative effects of CUR are estrogen-dependent in ER-positive MCF-7 breast cancer cells. ${ }^{46}$ These findings suggest that CUR acts through estrogen receptors to demonstrate its anticancer effects in hormone-dependent breast cancer cells. However, our results indicate that CUR-induced effects are not mediated via ER $\alpha$. These results are supported 


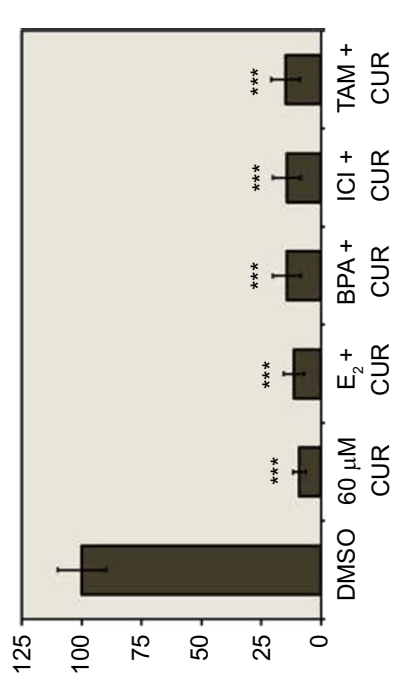

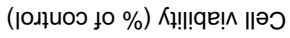
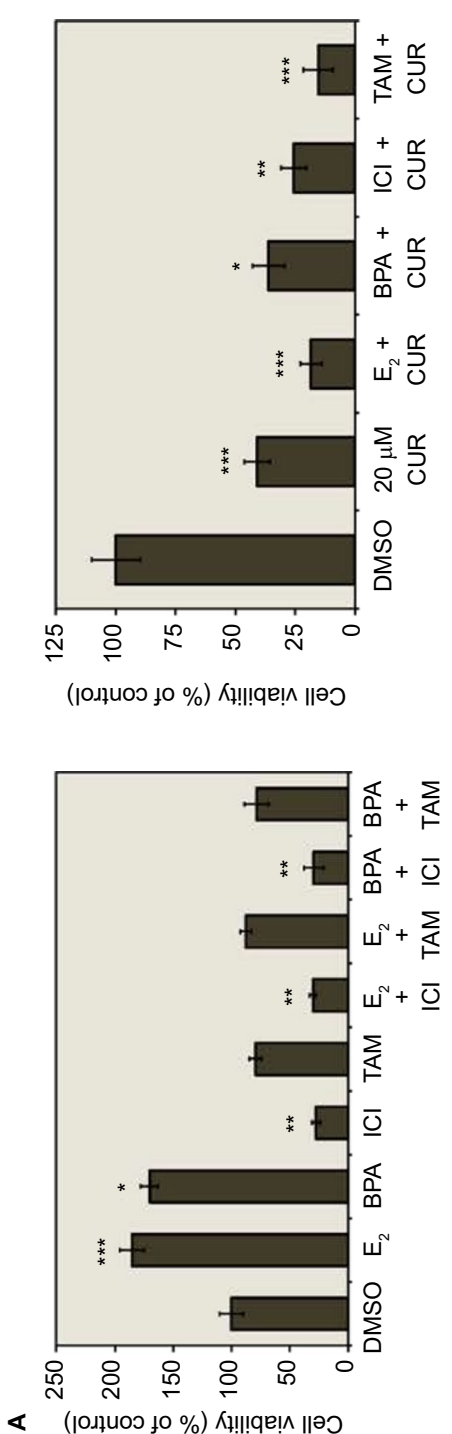
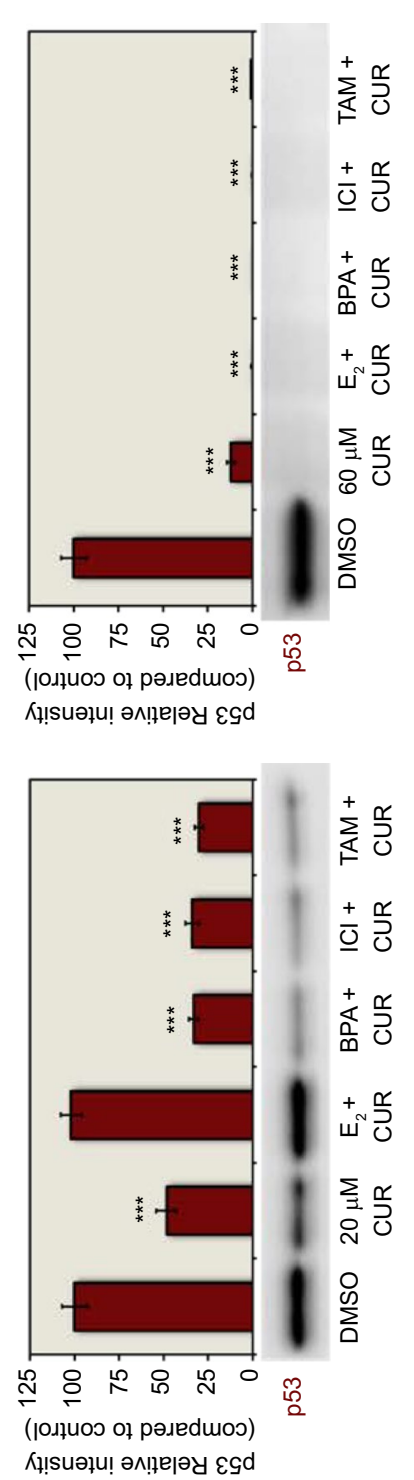

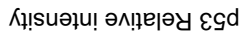

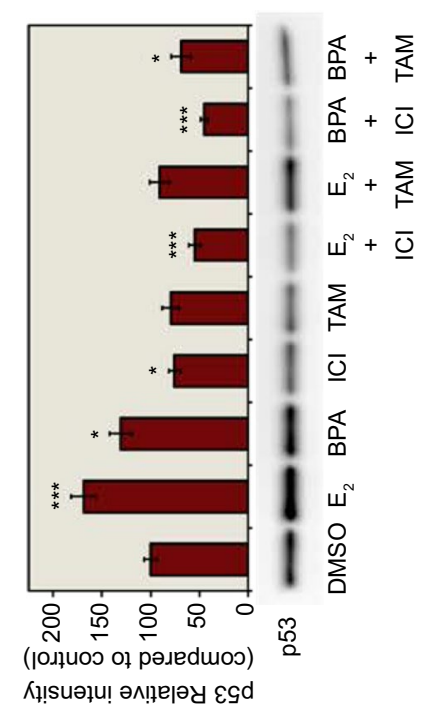

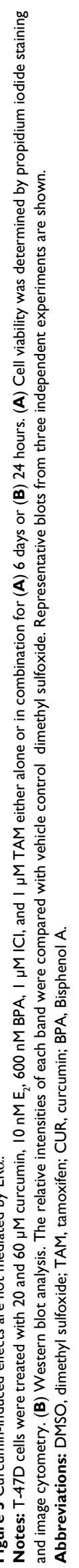


by the findings of CUR having antiproliferative effects on the ER-negative MDA-MB-231 breast cancer cell line, and these effects do not depend on the presence of estrogen. ${ }^{46}$ When MDA-MB-231 cells are treated with a combination of CUR and epigallocatechin gallate, another polyphenolic compound, antiproliferative effects are still present, further suggesting that the effects of CUR do not involve ER $\alpha .^{26}$

It remains clear that 20-80 $\mu \mathrm{M}$ CUR affects p53 and ER $\alpha$ protein expression on a molecular level. Whether these two proteins, known to contribute to the formation and progression of hormone-dependent breast cancer, are regulated on a transcriptional or translational level remains unclear. Although several studies have indicated estrogen-dependent effects of CUR, our results demonstrate effects that are not dependent on the presence of estrogen. Therefore, the effectiveness of CUR on hormone-dependent breast cancer cells needs to be re-evaluated. CUR has been studied as a chemopreventive agent in numerous clinical trials, and its effects should be further examined in vivo as well as in vitro. ${ }^{35-39}$ Further studies are warranted as our results support the potential and suitability of CUR as a treatment modality in hormone-dependent breast cancer.

\section{Acknowledgment}

Amy E Siebert is currently working in Department of Biological Sciences at Oakland University.

\section{Disclosure}

The authors report no conflicts of interest in this work.

\section{References}

1. Wiechmann L, Kuerer HM. The molecular journey from ductal carcinoma in situ to invasive breast cancer. Cancer. 2008;112(10):2130-2142.

2. Vaidya Y, Vaidya P, Vaidya T Ductal carcinoma in situ of the breast. Indian J Surg. 2015;77(2):141-146.

3. Cowell CF, Weigelt B, Sakr RA, et al. Progression from ductal carcinoma in situ to invasive breast cancer: revisited. Mol Oncol. 2013;7(5): 859-869.

4. Choudhuri T, Pal S, Agwarwal ML, Das T, Sa G. Curcumin induces apoptosis in human breast cancer cells through p53-dependent Bax induction. FEBS Lett. 2002;512(1-3):334-340.

5. Mudduluru G, George-William JN, Muppala S, et al. Curcumin regulates miR-21 expression and inhibits invasion and metastasis in colorectal cancer. Biosci Rep. 2011;31(3):185-197.

6. Deguchi A. Curcumin targets in inflammation and cancer. Endocr Metab Immune Disord Drug Targets. 2015;15(2):88-96.

7. Charpentier M.S, Whipple RA, Vitolo MI, et al. Curcumin targets breast cancer stem-like cells with microtentacles that persist in mammospheres and promote reattachment. Cancer Res. 2014;74(4):1250-1260.

8. Mukherjee S, Mazumdar M, Chakraborty S, et al. Curcumin inhibits breast cancer stem cell migration by amplifying the E-cadherin/ $\beta$ catenin negative feedback loop. Stem Cell Res Ther. 2014;5(5):116.

9. Kunnumakkara AB, Anand, P, Aggarwal, BB. Curcumin inhibits proliferation, invasion, angiogenesis and metastasis of different cancers through interaction with multiple cell signaling proteins. Cancer Lett. 2008;269(2):199-225.
10. Mukhopadhyay A. Curcumin-induced suppression of cell proliferation correlates with down-regulation of cyclin D1 expression and CDK4-mediated retinoblastoma protein phosphorylation. Oncogene. 2002;21(57):8852-8861.

11. Verma SP, Goldin BR, Lin PS. The inhibition of the estrogenic effects of pesticides and environmental chemicals by curcumin and isoflavonoids. Environ Health Perspect. 1998;106(12):807-812.

12. Sarkar FH, Li Y, Wang Z, Padhye S. Lesson learned from nature for the development of novel anti-cancer agents: implication of isoflavone, curcumin, and their synthetic analogs. Curr Pharm Des. 2010;16(16): 1801-1812.

13. Zhou H, Beevers CS, Huang, S. The targets of curcumin. Curr Drug Targets. 2011;12(3):332-347.

14. Prasad CP, Rath G, Mathur S, Bhatnagar D, Ralhan R. Potent growth suppressive activity of curcumin in human breast cancer cells: Modulation of Wnt/ $\beta$-catenin signaling. Chem Biol Interact. 2009;181(2):263-271.

15. Zhan Y, Chen Y, Liu R, Zhang H, Zhang Y. Potentiation of paclitaxel activity by curcumin in human breast cancer cell by modulating apoptosis and inhibiting EGFR signaling. Arch Pharm Res. 2014;37(8):1086-1095.

16. Prasad CP, Rath G, Mathur S, Bhatnagar D, Ralhan R. Expression analysis of maspin in invasive ductal carcinoma of breast and modulation of its expression by curcumin in breast cancer cell lines. Chem Biol Interact. 2010;183(3):455-461.

17. Chen B, Zhang Y, Wang Y, Rao J, Jiang X, Xu Z. Curcumin inhibits proliferation of breast cancer cells through Nrf2-mediated down-regulation of Fen1 expression. J Steroid Biochem Mol Biol. 2014;143:11-18.

18. Kim B, Kim HS2, Jung EJ et al. Curcumin induces ER stress-mediated apoptosis through selective generation of reactive oxygen species in cervical cancer cells. Mol Carcinog. 2016;55(5):918-928.

19. Guan F, Ding Y, Zhang Y, Zhou Y, Li M, Wang C. Curcumin suppresses proliferation and migration of MDA-MB-231 breast cancer cells through autophagy-dependent akt degradation. PLoS One. 2016; 11(1):e0146553.

20. Kim SR, Park HJ, Bae YH, et al. Curcumin down-regulates visfatin expression and inhibits breast cancer cell invasion. Endocrinology. 2012;153(2):554-563.

21. Kim HI, Huang H, Cheepala S, Huang S, Chung J. Curcumin inhibition of integrin ( $\alpha 6 \beta 4)$-dependent breast cancer cell motility and invasion. Cancer Prev Res. 2008;1(5):385-391.

22. Guo J, Li W, Shi H, et al. Synergistic effects of curcumin with emodin against the proliferation and invasion of breast cancer cells through upregulation of miR-34a. Mol Cell Biochem. 2013;382(1):103-111.

23. Sun K, Duan X, Cai H, et al. Curcumin inhibits LPA-induced invasion by attenuating RhoA/ROCK/MMPs pathway in MCF7 breast cancer cells. Clin Exp Med. 2016;16(1):37-47.

24. Patel PB, Thakkar, VR, Patel JS. Cellular effect of curcumin and citral combination on breast cancer cells: induction of apoptosis and cell cycle arrest. J Breast Cancer. 2015;18(3):225-234.

25. De Gasperi M, Cavazos D, deGraffenried L. Curcumin modulates tamoxifen response in resistant breast cancer cells. Cancer Res. 2009; 69(24 Suppl):3098.

26. Somers-Edgar TJ, Scandlyn MJ, Stuart EC, Le Nedelec MJ, Valentine SP, Rosengren RJ. The combination of epigallocatechin gallate and curcumin suppresses ER $\alpha$-breast cancer cell growth in vitro and in vivo. Int J Cancer. 2008;122(9):1966-1971.

27. Sun A, Lu YJ, Hu H, Shoji M, Liotta DC, Snyder JP. Curcumin analog cytotoxicity against breast cancer cells: exploitation of a redox-dependent mechanism. Bioorg Med Chem Lett. 2009;19(23):6627-6631.

28. Kakarala M, Brenner DE, Korkaya H, et al. Targeting breast stem cells with the cancer preventive compounds curcumin and piperine. Breast Cancer Res Treat. 2010;122(3):777-785.

29. Al-Hujaily EM, Mohamed AG, Al-Sharif I, et al. PAC, a novel curcumin analogue, has anti-breast cancer properties with higher efficiency on ER-negative cells. Breast Cancer Res Treat. 2011;128(1):97-107.

30. Mohankumar K, Pajaniradje S, Sridharan S, et al. Mechanism of apoptotic induction in human breast cancer cell, MCF-7, by an analog of curcumin in comparison with curcumin - An in vitro and in silico approach. Chemico-Biol Interact. 2014;210:51-63. 
31. Wang S, Chen R, Zhong Z. Epigallocatechin-3-gallate potentiates the effect of curcumin in inducing growth inhibition and apoptosis of resistant breast cancer cells. Am J Chin Med. 2014;42(5):1279-1300.

32. Mohankumar K, Sridharan S, Pajaniradje S, et al., BDMC-A, an analog of curcumin, inhibits markers of invasion, angiogenesis, and metastasis in breast cancer cells via NF- $\mathrm{KB}$ pathway-a comparative study with curcumin. Biomed Pharmacother. 2015;74:178-186.

33. Yallapu MM, Othman SF, Curtis ET, et al. Curcumin-loaded magnetic nanoparticles for breast cancer therapeutics and imaging applications Int J Nanomed. 2012;7:1761-1779.

34. Anitha A, Maya S, Deepa N, et al. Efficient water soluble O-carboxymethyl chitosan nanocarrier for the delivery of curcumin to cancer cells. Carbohydrate Polymers. 2011;83(2):452-461.

35. Kanai M, Otsuka Y, Otsuka K, et al. A phase I study investigating the safety and pharmacokinetics of highly bioavailable curcumin (Theracurmin () in cancer patients. Cancer Chemother Pharmacol. 2013;71(6):1521-1530.

36. Shehzad A, Wahid F, Lee YS. Curcumin in cancer chemoprevention: molecular targets, pharmacokinetics, bioavailability, and clinical trials. Arch Pharm. 2010;343(9):489-499.

37. Dhillon N, Aggarwal BB, Newman RA, et al. Phase II trial of curcumin in patients with advanced pancreatic cancer. Clin Cancer Res. 2008; 14(14):4491-4499.

38. Carroll RE, Benya RV, Turgeon DK, et al. Phase II a clinical trial of curcumin for the prevention of colorectal neoplasia. Cancer Prev Res. 2011;4(3):354-364.

39. Sharma RA, Euden SA, Platton SL, et al. Phase I clinical trial of oral curcumin: biomarkers of systemic activity and compliance. Clin Cancer Res. 2004;10(20):6847-6854.

40. Nejati-Koshki K, Akbarzadeh A, Pourhassan-Moghaddam M. Curcumin inhibits leptin gene expression and secretion in breast cancer cells by estrogen receptors. Cancer Cell Int. 2014;14:66.

41. Liontas A, Yeger H. Curcumin and resveratrol induce apoptosis and nuclear translocation and activation of p53 in human neuroblastoma Anticancer Res. 2004;24(2B):987-998.

42. Moos PJ, Edes K, Mullally JE, Fitzpatrick FA. Curcumin impairs tumor suppressor p53 function in colon cancer cells. Carcinogenesis. 2004;25(9):1611-1617.

43. Berglind H, Pawitan Y, Kato S, Ishioka C, Soussi T. Analysis of p53 mutation status in human cancer cell lines: a paradigm for cell line cross-contamination. Cancer Biol Ther. 2008;7(5):699-708.

44. Lim LY, Vidnovic N, Ellisen LW, Leong CO. Mutant p53 mediates survival of breast cancer cells. Br J Cancer. 2009;101(9):1606-1612.
45. Gartel AL, Feliciano C, Tyner TL. A new method for determining the status of p53 in tumor cell lines of different origin. Oncol Res. 2003; 13(6-10):405-408.

46. Shao ZM, Shen ZZ, Liu CH, et al. Curcumin exerts multiple suppressive effects on human breast carcinoma cells. Int J Cancer. 2002; 98(2):234-240.

47. Siebert AE, Sanchez AL, Dinda S, Moudgil VK. Effects of estrogen metabolite 2-methoxyestradiol on tumor suppressor protein p53 and proliferation of breast cancer cells. Syst Biol Reprod Med. 2011;57(6):279-287.

48. Hurd C, Khattree N, Alban P, et al. Hormonal regulation of the p53 tumor suppressor protein in T47D human breast carcinoma cell line. J Biol Chem. 1995;270(48):28507-28510.

49. Dinda S, SanchezA, Moudgil VK. Effects of LY117018 (a SERM analog of raloxifene) on tumor suppressor proteins and proliferation of breast cancer cells. Horm Mol Biol Clin Investig. 2010;2(1):211-217.

50. Laïos I, Journé F, Nonclercq D, et al. Role of the proteasome in the regulation of estrogen receptor $\alpha$ turnover and function in MCF-7 breast carcinoma cells. J Steroid Biochem Mol Biol. 2005;94(4):347-359.

51. Yeh WL, Shioda K, Coser KR, Rivizzigno D, McSweeney KR, Shioda T. Fulvestrant-induced cell death and proteasomal degradation of estrogen receptor? Protein in $\mathrm{MCF}-7$ cells require the CSK c-Src tyrosine kinase. PLoS One. 2013;8(4):e60889.

52. Ji Z, Tang Q, Zhang J, Yang Y, Liu Y, Pan Y. Oridonin-induced apoptosis in SW620 human colorectal adenocarcinoma cells. Oncol Lett. 2011;2(6):1303-1307.

53. Berger EA, McClellan SA, Vistisen KS, Hazlett LD. HIF-1 $\alpha$ is essential for effective PMN bacterial killing, antimicrobial peptide production and apoptosis in Pseudomonas aeruginosa keratitis. PLoS Pathog 2013;9(7):e1003457.

54. Yedjou CG, Saeed MA, Hossain MA, Dorsey W, Yu H, Tchounwou PB. Basic apoptotic and necrotic cell death in human liver carcinoma (HepG2 ) cells induced by synthetic azamacrocycle. Environ Toxicol. 2014;29(6):605-611.

55. Chan LL, Lai N, Wang E, Smith T, Yang X, Lin B. A rapid detection method for apoptosis and necrosis measurement using the cellometer imaging cytometry. Apoptosis. 2011;16(12):1295-1303.

56. Liu Q, Loo WT, Sze SC, Tong Y. Curcumin inhibits cell proliferation of MDA-MB-231 and BT-483 breast cancer cells mediated by downregulation of NFKB, cyclinD and MMP-1 transcription. Phytomedicine 2009;16(10):916-922.

57. Liu D, Chen Z. The effect of curcumin on breast cancer cells. J Breast Cancer. 2013;16(2):133-137.
Breast Cancer - Targets and Therapy

\section{Publish your work in this journal}

Breast Cancer - Targets and Therapy is an international, peerreviewed open access journal focusing on breast cancer research, identification of therapeutic targets and the optimal use of preventative and integrated treatment interventions to achieve improved outcomes, enhanced survival and quality of life for the cancer patient
Dovepress

The manuscript management system is completely online and includes a very quick and fair peer-review system, which is all easy to use. Visit http://www.dovepress.com/testimonials.php to read real quotes from published authors. 